\title{
SEMIAHMOO INDIAN BAND v. CANADA
}

\author{
BOB FREEDMAN*
}

\section{INTRODUCTION}

In Guerin v. R.,' the Supreme Court of Canada held that the Crown owes a fiduciary duty to First Nations. Since the Guerin decision, Canadian courts have attempted to set out the nature of the fiduciary relationship between the Crown and First Nations. In $R$ v. Sparrow, ${ }^{2}$ the Supreme Court of Canada expanded the fiduciary concept developed in Guerin to say that s. 35 of the Constitution Act, $1982^{3}$ must be read in light of the Crown's fiduciary duty. While Guerin and Sparrow are important decisions and give legal force to the Crown-First Nation relationship by imposing a fiduciary duty therein, there has been little guidance provided by the courts concerning exactly what the legal ramifications of this relationship are. ${ }^{4}$

What has been strikingly absent in these decisions is any attempt to subject the Crown, in its dealings with First Nations, to basic principles that would apply to any fiduciary. In other words, although we know that the Crown owes some sort of "duty" to First Nations, courts have applied this concept in a number of bizarre ways which attempt to explain away or entirely ignore basic tenets of the law of fiduciaries, such as the requirement that fiduciaries must act in utmost good faith, that fiduciaries must act in the best interests of beneficiaries, that fiduciaries cannot benefit from their positions, and that fiduciaries cannot compromise the interests of their beneficiaries. ${ }^{6}$ Rather than ensuring that First Nations are protected by these core principles of the law of fiduciary obligation, the courts have tended to focus on various defences or excuses offered by the Crown such as: the Crown has conflicting duties; a particular transaction

B.A. (New College); M.P.A., LL.B. (Queen's); LL.M. (Virginia). Mr. Freedman practices in the area of First Nations law at Ratcliff \& Company in North Vancouver, British Columbia.

(1984), 13 D.L.R. (4th) 321 (S.C.C.) [hereinafter Guerin].

(1990), 70 D.L.R. (4th) 385 (S.C.C.) [hereinafter Sparrow].

Schedule B to the Canada Act 1982 (U.K.), 1982, c. 11.

There are many judicial decisions which have attempted to apply the fiduciary concept. For a discussion of many of these cases and the problems inherent in the decisions, see L.I. Rotman, Parallel Paths: Fiduciary Doctrine and the Crown-Native Relationship in Canada (Toronto: University of Toronto Press, 1996). Also see B. Slattery, "First Nations and the Constitution: A Question of Trust" (1992) 71 Can. Bar Rev. 261; W.R. McMurtry \& A. Pratt, "Indians and the Fiduciary Concept, Self-Government and the Constitution: Guerin in Perspective," [1986] 3 C.N.L.R. 19; and R.H. Bartlett, "The Fiduciary Obligation of the Crown to the Indians" (1989) 53 Sask. L. Rev. 301.

5 Some of the more noteworthy cases in this regard include Blueberry River Indian Band v. Canada (Department of Indian Affairs and Northern Development) (1995), 130 D.L.R. (4th) 193 (S.C.C.) [hereinafter Apsassin]; R. v. Roberts (1995), 99 F.T.R. 1 (T.D.); Kruger v. R. (1985), 17 D.L.R. (4th) 591 (F.C.A.); and Lower Kootenay Indian Band v. Canada, [1992] 2 C.N.L.R. 54 (F.C.T.D.). 
was at arm's length; the Crown obtained the best value at the time; independent legal advice was obtained; and full disclosure was made. ${ }^{7}$

Even when courts have found that the Crown breached its fiduciary obligations to a particular First Nation, the claim has usually been denied on the basis that the time for bringing the claim had expired pursuant to the relevant limitations legislation. Perhaps the most obvious recent example of the application of limitations periods to the detriment of First Nations is found in Apsassin. ${ }^{8}$ In that case, a significant portion of the claim was dismissed on the basis that the British Columbia Limitation Act (R.S.B.C. 1979 , c. 236) precluded any claim being advanced beyond an ultimate limitation period of thirty years. Little or no analysis was provided on the key question of when such time should begin to run.

Recently, in Semiahmoo Indian Band v. Canada, ${ }^{9}$ the Federal Court of Appeal has taken an important step forward in beginning to apply fiduciary law critically in order to determine the duties owed by the Crown to First Nations. In particular, the Court refused to hide behind the mask of Crown excuses in deciding the case. Instead, the Court applied some of the core principles which should be inherent in any fiduciary relationship.

In this comment, the Semiahmoo decision will be examined with particular focus on the unique approach taken by the Federal Court of Appeal and its potential implications for First Nations across Canada. At the same time, many of the questions raised by this decision will be set out. Although the primary focus of the case comment will be on the Court's discussion of fiduciary duty, it is important to note that the case also deals with the way in which limitation periods are to be applied to First Nations. This aspect of the Semiahmoo decision will also be explored.

\section{FACTS}

In 1889, the federal Crown designated approximately 382 acres of land in British Columbia as reserve land for the use and benefit of the Semiahmoo Indian Band within the meaning of the Indian Act. At various times, the Crown "took back" lands from this reserve. At issue in the case was the absolute surrender of 22.048 acres of the land obtained by the Crown in 1951 .

The Crown had made various overtures to the Band beginning in 1949 in which it sought to obtain part of the reserve to expand the customs facility at the Douglas Border Crossing in British Columbia. In the fall of 1951, the Crown made an official proposal to the Band for the surrender of 22.048 acres, although not all of the land was immediately needed for a customs facility. On 3 November 1951, the Band agreed to Kootenay Indian Band v. Canada, supra note 5. 
an absolute surrender of 22.048 acres for $\$ 550$ per acre. No appraisal was done before setting this price.

The trial judge found that "in the normal course of events," the Band would not have surrendered the land, although they might have been predisposed to subdivide it for occupation by others under long-term leases. The Band was aware that the Crown had the right to expropriate the land for public purposes if it refused to surrender it.

Since 1951, the Crown has retained title to the surrendered lands, although little has been used for customs facilities or for any other public purpose. On many occasions after 1951, the Band asked the Crown about its intended use of the surrendered land and whether some of the land could be returned to the Band since it did not appear to be required for a public purpose. In 1969, the Band learned that the land was not going to be used to expand the customs facility in the foreseeable future. There was even correspondence within the government saying that some of the land should be returned to the Band.

In 1969, the Band passed a Band Council Resolution ("BCR") recommending that the Department of Indian and Northern Affairs ("DIAND") take immediate action to return the 22.048 acres. DIAND agreed with the Band and made inquiries to the Minister of Public Works ("MPW") and the Minister of National Revenue ("MNR"). MNR refused to release the surrendered land "due to foreseeable expansion requirements" for the customs facility. MPW then backtracked from its previous view that the land should be returned, saying that it was the Band which had to show that the land could be put to beneficial use in order for it to be returned.

For several more years, the Band continued efforts to have the land returned. It was told that the land was needed for foreseeable expansion of the customs facility, or that studies were being prepared in respect of the use of this land.

Finally, in 1987, the Band retained legal counsel in an attempt to obtain information regarding the use of the site. The following year, MPW commissioned a study on possible interim uses of the surrendered lands. The study suggested that the land might be used for a resort. This report also considered the fact that most of the Semiahmoo Indian Reserve was in its "natural state" to be a positive factor for the proposed development of the resort. The Band did not obtain a copy of this report until 23 May 1989.

\section{The Band's Claim in Federal Court}

The Band filed their statement of claim on 3 July 1990, alleging that the Crown had breached its fiduciary duty in respect of the 1951 surrender. The Band alleged that the price paid for the land in the original surrender was inadequate and that the respondent failed to protect the best interests of the Band when it consented to an absolute surrender of the land, even though the Crown did not have a foreseeable use in mind for the land at the time that it consented to, and encouraged the Band to consent to, the 1951 surrender. 


\section{Decision of THE Trial Judge}

The trial judge, Reed J., found that there was no evidence to support the Band's claim that the price paid for the land in 1951 was below market value. Reed J. also noted that there was no term, express or implied, in the surrender agreement which required that the land be returned to the Band if it was not used to expand the customs facility. Nevertheless, she concluded that the Crown had breached its duty to the Band in consenting to the 1951 surrender, on the basis that the Crown should have taken the course of action which least impaired the rights of the Band.

Despite the finding of breach of fiduciary duty, the trial judge held that the Band's claim was barred by operation of the British Columbia Limitation Act. Reed J. based her decision on the 1951 surrender as triggering the limitation period, which she said would have either expired after six years ${ }^{10}$ in 1957 or at the latest after thirty years, ${ }^{11}$ in 1981 .

\section{Decision of the Federal Court of ApPeal}

In a unanimous decision, written by Isaac C.J. (McDonald and Gray JJ.A., concurring), the Federal Court of Appeal allowed the Band's appeal, holding that the Crown had breached its fiduciary duty, and that the action was not barred by operation of the Limitation Act. The decision of the Federal Court of Appeal deals with three main topics: the Crown's breach of duty, limitations issues, and remedies. Discussion in this case comment will focus on the Court's decision concerning breach of fiduciary duty and application of limitations legislation.

\section{The Crown's Breach of Fiduciary DUTY}

The Federal Court of Appeal made a number of important points in relation to the law concerning breach of fiduciary duty. The Court said that the surrender requirement is the source of the Crown's fiduciary obligation to First Nations. ${ }^{12}$ The Court went on to say that, in Apsassin, the Supreme Court of Canada focused on the word "exploited" in Guerin to refine the scope of the Crown's fiduciary obligation. The Court referred, with approval, to the following passage in the decision of McLachlin J. in Apsassin:

The six year limitation period, which covers actions which are not otherwise enumerated in the Limitation Act, such as a claim for breach of fiduciary duty, is found in s. 3(4), which is worded in this way:

Any other action not specifically provided for in this Act or any other Act shall not be brought after the expiration of 6 years after the date on which the right to do so arose. The "ultimate" limitation of thirty years is found in s. 8(1) of the Limitation Act:

Subject to s. 3(3), but notwithstanding a confirmation under s. 5 or a postponement or suspension of the running of time under ss. 6,7 or 12, no action to which this Act applies shall be brought after the expiration of 30 years on which the right to do so arose.

The thirty year ultimate limitation period has been the source of much judicial consideration. Most recently, in Apsassin, supra note 4, the Supreme Court of Canada held that, although some of the shorter limitation periods in the Limitation Act can be postponed in certain instances, none of the limitation periods can be postponed beyond thirty years. 
It follows that under the Indian Act, the Band had the right to decide whether to surrender the reserve, and its decision was to be respected. At the same time, if the Band's decision was foolish or improvident - a decision that constituted exploitation - the Crown could refuse to consent. In short, the Crown's obligation was limited to preventing exploitative bargains. ${ }^{13}$

A number of important questions are raised by this passage, many of which are not answered by the Federal Court of Appeal in the Semiahmoo decision. Perhaps the most important question is, quite simply, what sort of behaviour will constitute "exploitation" such that it will trigger a breach of duty? Must there be a consistent course of conduct by the Crown which is exploitative? Will the focus be on the Crown's behaviour over a period of time, or will it be on the result of transactions viewed in isolation from one another? In other words, will the Crown be permitted to say that it obtained the best value for a piece of land, even if it otherwise acted improperly? What happens when it is the Crown, rather than a third party, who has exploited the Indians and ended up with the property? The Court in Semiahmoo said that, on the facts of the case, "the Band felt powerless to decide any other way." 14 At a minimum, a bargain will be exploitative if the Crown exerts pressure or acts in a way that gives a Band no other choice but to acquiesce.

How will the question of whether the Band's decision was "foolish and improvident" be determined? In Apsassin, McLachlin J. said that "the duty on the Crown as fiduciary was 'that of a man of ordinary prudence in managing his own affairs."'15 How will this standard be applied to First Nations? Will the test be objective or subjective? It may be that a "man of ordinary prudence" would choose to sell land at market value at a given time. However, how are we to know whether such a decision would be "foolish and improvident" for a particular First Nation? It is perhaps trite to say that land often has a unique importance to First Nations beyond its economic value. In Semiahmoo, the Court referred to the land in question as a "unique property." Will this be taken into account in other cases in determining whether a decision was "foolish and improvident" or whether it complied with the actions of "a man of ordinary prudence in managing his own affairs"?

In virtually all cases dealing with reserve land, the Crown has considerable power over Indian Bands by virtue of the surrender requirement contained in s. 37 of the Indian Act, R.S.C. 1985, c. I-5. The evidence in the Semiahmoo case indicated that land had been taken from the Band by expropriation in the past, and before 1951, MPW considered taking the 22.048 acres by expropriation as well. Thus, the Band's decision to consent to the 1951 surrender was significantly influenced by this knowledge, so that the Band felt that if they did not surrender the land at $\$ 550$ per acre, the land may well have been expropriated in any event. The Court noted:

The Trial Judge found that the Band would not have surrendered the land "in the normal course of events," although "...they might have been predisposed to subdivide it for occupation by others under 
long-term leases." The Band knew at all times that the respondent had the right to expropriate the land for public purposes if the Band refused to surrender it. ${ }^{16}$

This part of the decision is quite important. It indicates that the Crown might pursue a course of conduct which has the effect of breaching its duty, such as by inadequate disclosure, misrepresentation, or exertion of undue influence. Whereas in Apsassin, McLachlin J. referred to the "conflicting political pressures in favour of preserving the land for the Band on the one hand, and making it available for distribution to veterans on the other," ${ }^{17}$ and to questions surrounding the adequacy of prices obtained for the land, the approach in Semiahmoo focuses on the behaviour of the Crown. If the Crown's behaviour is improper, and if it fails to discharge its core fiduciary duties properly, it should be irrelevant whether or not the Crown obtained the best price at the time.

With respect to the market value of the lands in 1951, whereas the trial judge had found that $\$ 550$ per acre was not below market value, the Court of Appeal said that this does not negate the Crown's fiduciary duty. It asserted that "[t]he focus in determining whether or not the respondent breached its fiduciary duty must be on the extent to which the respondent protected the best interests of the Band while also acknowledging the Crown's obligation to advance a legitimate public purpose."18 It was found that the Band did not want to surrender the land at all but felt it had no choice. In any event, by not looking to other options, such as leasing, or a conditional surrender, the Crown did not impair the Band's rights to the least possible extent.

The Court noted that when the 1951 surrender was obtained, there was no attempt made by the Crown in drafting its terms to minimize the impairment of the Band's rights. ${ }^{19}$ As such, the Crown should have exercised its discretion to withhold its consent to the surrender or to ensure that the surrender was qualified or conditional, rather than absolute. In particular, the Court said the following:

\footnotetext{
Having regard to the circumstances of this case, I am in respectful agreement with the Trial Judge's characterization of the respondent's pre-surrender fiduciary duty. I also agree with the Trial Judge's conclusion, based on the facts, that the respondent breached this duty when it consented to the 1951 surrender. In my view, the 1951 surrender agreement, assessed in the context of the specific relationship between the parties, was an exploitative bargain. No attempt was made in drafting its terms to minimize the impairment of the Band's rights, and therefore, the respondent should have exercised its discretion to withhold its consent to the surrender or to ensure that the surrender was qualified or conditional. ${ }^{20}$
}

This may be the most important aspect of the Court's decision.

Ibid. at para. 7.

Apsassin, supra note 5 at 214 (para. 53).

Semiahmoo, supra note 9 at para. 46 [emphasis added].

Ibid. at para. 41.

lbid. [emphasis added]. 
The Court said that the Crown, as fiduciary, was required to ensure that the Band's rights were impaired to the least possible extent. This indicates that the Crown must scrutinize all transactions and advise the Band whether to lease, sell, or do nothing in a given circumstance. The Crown's duty is a positive one; it cannot sit back and wait for the Band to raise questions about the propriety of a given transaction. The Crown cannot escape its duties because it has conflicting duties. At an absolute minimum, the Crown is required to put in appropriate safeguards to ensure minimal impairment of a Band's rights. The Crown's behaviour must be "assessed in the context of the specific relationship between the parties."

In focusing on the Crown's behaviour, rather than on the value obtained in the 1951 lease, the Court reiterated that "the Band's ability to give or to withhold their own consent to the absolute surrender in 1951 was fettered by their knowledge of the respondent's power to expropriate."21 It further noted:

The respondent's assertion that the Band gave full and informed consent to the absolute surrender rings hollow in the face of these findings. In my respectful view, in finding that the Band surrendered their land to the respondent despite the fact that they "would not have surrendered the land, in the normal course of events" the Trial Judge concluded, based on the evidence, that the Band felt powerless to decide in any other way. The bargain, in other words, was exploitative. ${ }^{22}$

The Court said that the Band did not give its full and informed consent despite the assertions of the Crown to the contrary. This finding is significant, as it indicates that in order for the Crown to discharge its fiduciary duty the Band must have full and complete information upon which to base a decision, and the Band must give its "informed consent." ${ }^{23}$ In this case, it was found that the Band felt powerless to decide in any other way.

The Court also said that "the Crown's fiduciary obligation is to withhold its own consent to surrender where the transaction is exploitative."24 This finding is also significant, as the Crown itself is required to scrutinize the proposed transaction to ensure that it is not an exploitative bargain. Again, this is a positive duty on the Crown. Even if the land is used for a public purpose, the Crown cannot discharge its fiduciary obligation simply by convincing the Band to accept the surrender and then use the Band's consent to relieve itself of the responsibility to scrutinize the transaction. In other words, there is some positive duty on the Crown to give full information to the

Ibid. at para. 43.

lbid. at para. 44 [emphasis added].

There are a number of cases which say that, in order for a fiduciary to properly discharge his or her duties, the beneficiary must give his or her informed consent. While there may be some argument as to whether this standard applies only where the fiduciary intends to profit from a transaction, in any event, where the Crown continues to hold property, such as was the case in Semiahmoo, then the Crown continues to profit from this sort of transaction. Some of the cases include: Canadian Aero v. O'Malley (1974), 40 D.L.R. (3d) 271 (S.C.C.); Baillie v. Charman, [1993] 1 W.W.R. 232 (B.C.C.A.); and Hospital Products Ltd. v. United States Surgical Corp. (1984) 54 A.L.R. 417 (H.C. Aust).

Semiahmoo, supra note 9 at para. 45 [emphasis added]. 
Band and to ensure that the bargain is not exploitative. The Crown cannot simply accept the Band's decision in satisfaction of its fiduciary obligations. It was found that the Crown encouraged the Band to surrender part of its reserve; it did not act in a way which protected the Band's rights.

Once again, the question is how McLachlin J.'s description in Apsassin of the surrender provisions in the Indian Act as "a balance between the two extremes of autonomy and protection" will play out. ${ }^{25}$ At a minimum, as noted above, the Federal Court of Appeal held that the Crown must take a positive role in scrutinizing transactions in order to protect a Band. In this respect, the Court said that:

The respondent should not have consented to the absolute surrender, at least not without first ensuring that it contained appropriate safeguards, such as a reversionary clause, to ensure the least possible impairment of the Band's rights.

I should emphasize that the Crown's fiduciary obligation is to withhold its own consent to surrender where the transaction is exploitative. In order to fulfil this obligation, the Crown itself is obliged to scrutinize the proposed transaction to ensure that it is not an exploitative bargain. As a fiduciary, the Crown must be held to a strict standard of conduct. Even if the land at issue is required for a public purpose, the Crown cannot discharge its fiduciary obligation simply by convincing the Band to accept the surrender, and then using this consent to relieve itself of the responsibility to scrutinize the transaction. The Trial Judge's findings of fact, however, suggest that this is precisely what the respondents did. ${ }^{26}$

Once again, the Crown must do more than simply sit back and wait for a First Nation to make inquiries. Furthermore, the Crown cannot simply point to a surrender document and say that a First Nation's signature on such a document is sufficient evidence of consent to a transaction. The Crown is obliged, as fiduciary, to scrutinize the transaction and to obtain a Band's informed consent. This finding is in line with the idea of a "duty to consult" as set out in a number of recent cases. ${ }^{27}$

It is interesting to contrast the decision in Semiahmoo respecting the requirement for full and informed consent - and the Court's recognition that the Band's ability to consent could be fettered by the Crown, such as through coercion, improper disclosure, and undue influence - with the decision in Apsassin. In Apsassin, Gonthier J. remarked:

The Band's intention is evidenced by the terms of the 1945 surrender instrument, signed by Chief Succona, Joseph Apsassin and two councillors on behalf of the Band. The instrument states that the Band did "release, remise, surrender, quit claim and yield up unto our Sovereign Lord the King, his Heirs and Successors forever.... ${ }^{28}$

26 Semiahmoo, supra note 9 at paras. 44-45 [emphasis in original].

27 See Sparrow, supra note 2 at $417 ; R$ v. Sampson, [1996] 5 W.W.R. 18 (B.C.C.A.); $R$ v. Jack, [1996] 5 W.W.R. 45 (B.C.C.A.); and R v. Little, [1996] 5 W.W.R. 69 (B.C.C.A.). 
One must question how the Band's intention can simply be inferred from a signature on a surrender document absent evidence that the Band was fully informed about the meaning and effect of the surrender and was aware of all options available to it. A signature on a document does not evince an informed consent. It is important to note that Gonthier J. commented that:

I would be reluctant to give effect to this surrender variation if I thought that the Band's understanding of its terms had been inadequate, or if the Crown had somehow tainted the dealings in a manner which made it unsafe to rely on the Band's understanding and intention. ${ }^{29}$

In Semiahmoo, it was found that the dealings were tainted. The Court remarked that "the Band did not want to surrender the land at all but felt it had no choice." The threat of expropriation loomed. ${ }^{30}$ It was also held that the Band had to, and did, rely upon the Crown's representations to the effect that the land was required for expansion of a customs facility, thereby implying that an absolute surrender was necessary. ${ }^{31}$ The Court held that while the express wording of the surrender instrument did not indicate that the land was being acquired for the purpose of a customs facility, nevertheless, the "oral terms" formed part of the circumstances that determined that the Crown acted unconscionably. Here, reference was made to the Guerin decision.

One is left with the question of exactly what sort of disclosure will be found sufficient to hold that a First Nation has given its informed consent in a particular transaction. While the Court focused on the Crown's improper behaviour and an improper course of conduct in Semiahmoo, in Apsassin both Gonthier and McLachlin $\mathrm{JJ}$. essentially relied on a number of questionable findings of the trial judge with respect to determining the Band's intention. alia:

McLachlin J. pointed to certain facts found by the trial judge which included, inter

1. That the plaintiffs had known for some considerable time that an absolute surrender of I.R. 172 was being contemplated;

2. That they had discussed the matter previously on at least three formal meetings where representatives of the department were present;

3. That, contrary to what has been claimed by the plaintiffs, it would be nothing short of ludicrous to conclude that the Indians would not also have discussed it between themselves on many occasions in an informal matter, in their various family and hunting groups;

4. That, at the surrender meeting itself, the matter was fully discussed both between the Indians and with the departmental representatives previous to the signing of the actual surrender; 
6. That Mr. Grew [the local Indian agent] fully explained to the Indians the consequences of a surrender;

7. That, although they would not have understood and probably would have been incapable of understanding the precise nature of the legal interest they were surrendering, they did in fact understand that by the surrender they were giving up forever all rights to I.R. 172, in return for the money which would be deposited to their credit once the reserve was sold and with their being furnished with altemate sites near their trapping lines to be purchased from the proceeds. ${ }^{32}$

What is "nothing short of ludicrous"33 is that the number of discussions, rather than the content of those discussions, is found to be sufficient to discharge the Crown's fiduciary duty to disclose information.

While McLachlin J. said that the Crown must provide the Band with "information as to its options and their foreseeable consequences," ${ }^{34}$ the Court made a rather large jump in accepting the trial judge's view that discussions about the consequences of a surrender fulfil this duty. The Band may have discussed the issue many times; that is irrelevant. Unless a Band understands all its options and their consequences, including the choice to keep land and do nothing, then it is unlikely that the Crown has properly discharged its fiduciary duty. How can a Band give its informed consent if it does not understand the nature of its legal rights?

The decision in Semiahmoo is a major improvement on the inadequate reasoning concerning the disclosure requirements of the Crown found in Apsassin. The test used by the Federal Court is not how many times did the Crown talk to the Indians, and how many times did the Indians talk amongst themselves. Rather, the Court understood that the Band relied on the Crown to provide information. The Court also recognized that the Crown's behaviour may taint the type and adequacy of the information provided. A more thorough analysis of the standard of disclosure required of the Crown, and the types of behaviour and information which will meet this standard, is needed in future decisions.

The decisions in Semiahmoo and Apsassin both recognize the need for a Band to have information. Neither case gives much guidance in determining how much information is sufficient to discharge the Crown's fiduciary duty. In Apsassin, the Crown's conduct is virtually ignored in respect of the duty of disclosure. While Semiahmoo is a superior decision in this regard, it does not set out in any detail what, exactly, constitutes the sort of conduct which would taint dealings such that a Band's consent or intention would be called into question. The closest the Court comes to 
shedding some light on this subject is to remark that "the Band felt powerless to decide any other way." 35

The Court held that in 1951 the Crown did not have any definite plans for construction of the expanded customs facility in the foreseeable future which necessitated the taking of 22.048 acres. In fact, no development plan was prepared for over forty years. This raises the question of whether the decision of the Court might have been different if the Crown had demonstrated a use for the land. The Court remarked that "[w]hile the Crown must be given some latitude in its land-use planning when it actively seeks the surrender of Indian land for a public purpose, the Crown must ensure that it impairs the rights of the affected Indian Band as little as possible, which includes ensuring that the surrender is for a timely public purpose." 36

In addition to the foregoing, the Court made some important points concerning whether the Crown can defend a claim of breach of fiduciary duty by saying that a particular transaction was done "at arm's length." The Court rejected the idea that the Crown could defend the claim on the basis that one department of the Crown may not be aware of the actions of another department. The Court noted that:

In this case, the Crown still owns the land and controls the Surrendered Land; land which was obtained by the Crown in breach of its fiduciary duty to the Band. In these circumstances, I am of the view that the Crown has a post-surrender fiduciary duty to correct the original breach. $l$ is a post-surrender duty which is owed by the Crown, and not simply by DIAND. The fact that Public Works, and not DIAND. is in possession of the Surrendered Land does not mean that the Crown is somehow shielded from its obligation to correct the breach of fiduciary duty committed in consenting to the exploitative bargain that was the original surrender agreement. ${ }^{37}$

This must be contrasted with the decision of the Supreme Court of Canada in Apsassin, as the two decisions appear to be at odds with one another on the issue of arm's length transactions.

In Apsassin, McLachlin J. said the following in response to the appellant's assertion that the Crown was under a continuing breach of duty:

Although the transfer was from one Crown entity to another, it remained a transfer and an alienation of title. First, the transfer converted the Band's interest from a property interest into a sum of money, suggesting alienation. Second, the continuing fiduciary duty proposed for the DVLA is problematic from a practical point of view.... Moreover, it is not clear that the DVLA had any knowledge of the fiduciary obligations which bound the DIA. In fact, the DVLA and DIA acted at arm's length throughout, as was appropriate given the different interests they represented and the different mandates of their statutes. ${ }^{38}$ 
This may be the most troubling aspect of the Apsassin decision.

The implication of this statement, if taken to an extreme, is that the Crown can transfer land internally so as to divest itself of its fiduciary duty to First Nations. This sort of finding is contrary to a basic tenet of fiduciary law, namely, that fiduciaries cannot delegate their authority to others absolutely. ${ }^{39}$ It also seems to impose an obligation on First Nations to determine how property is being dealt with by the Crown, in order to keep track of which department owes a fiduciary duty at a particular time. This places an impossible burden on First Nations and invites the Crown to act in a way which defeats the very purpose of imposing duties in the first place.

This idea was rejected by the Federal Court of Appeal in Semiahmoo. The Court said that the fact that MPW, and not DIAND, is in possession of the surrendered land does not mean that the Crown is somehow shielded from its obligations to correct the breach of fiduciary duty. The post-surrender duty is owed by the Crown generally, and not simply by DIAND.

Since Apsassin and Semiahmoo may be at odds in terms of the issue of "arm's length transactions," it may be that the safest route to take in advising a particular First Nation is to say that DIAND (or its predecessors) owe a fiduciary duty to act in the best interests of First Nations. If land is transferred, the duty remains in DIAND and any action for breach of fiduciary duty would focus on DIAND improperly alienating land or acting in some way which impaired a First Nations' rights. If DIAND chooses to alienate Indian lands to another department of the Crown, then it should be DIAND, rather than a First Nation, which is under a duty to determine whether such a transfer would be in breach of its fiduciary duty. Since it is the Crown, rather than a First Nation, that is usually in possession of relevant information, it seems nonsensical to permit the Crown to escape its duty by taking steps which are unknown to a First Nation. The duty to deal with Indian lands arises both pre- and post-surrender.

In addition to the foregoing, the Court also made the following points concerning the Crown's fiduciary duty:

1. The fact that the Indian Act is silent on the subjects of surrender variation, surrender revocation, and re-surrender does not mean that all surrenders are permanent and irrevocable.

2. The absence of a section like s. 64 of the Indian Act, $1927,{ }^{40}$ at issue in Apsassin, which empowered the Crown to correct erroneous transfers of surrendered lands, is not fatal to the existence of a post-surrender fiduciary

Section 64 of the Indian Act, 1927, R.S.C. 1927, c. 98 reads in part:

If the Superintendent General is satisfied that any purchaser or lessee of any Indian lands, or any person claiming under or through him, has been guilty of any fraud or imposition, or has violated any of the conditions of the sale or lease, or if any such sale or lease has been made or issued in error or mistake, he may cancel such sale or lease and resume the land therein mentioned, or dispose of it as if no sale or lease thereof had ever been made. 
duty on the Crown to act in the best interests of the Band in respect of surrendered land, particularly when the Crown still owns and controls the land, as s. 64 is not the source of the Crown's fiduciary duty. ${ }^{41}$

\section{OPERATION OF Limitations Legislation}

The Court made a number of interesting comments with respect to the operation of limitations legislation. The appellants attempted to argue that there was a fresh cause of action each time the Crown withheld material information after the surrender. While the Court found that this "continuing breach" argument had an "attractive ring," the argument was rejected:

While the respondent's post-surrender fiduciary duty can be seen as continuing so long as the respondent retains ownership and control over the land, I am of the view that any breach of that duty must be located at a specific point in time. It would defeat the very purpose of limitation periods to find that a breach of fiduciary duty continues for so long as the Crown retains the surrendered land. It is for this reason that the Supreme Court used an objective test for breach of fiduciary duty in Apsassin and prior cases. That is, a post-surrender breach of fiduciary duty by the Crown is pinpointed, for the purposes of limitation periods, at the point in time when a reasonable person would have realized their original breach and exercised their power to correct it. ${ }^{42}$

This raises the important question of how one determines when limitations periods begin to run.

In British Columbia, with the thirty year ultimate limitation period, this is particularly important. Although the Band's action was within the thirty year ultimate limitation period in respect of the 1969 breach, the Court said that this limitation operated in addition to the other limitation periods in the British Columbia Limitation Act. The Court quoted, with approval, the following passage in Apsassin: "the 6- and 10-year limitations, but not the general thirty year ultimate limitation, may be postponed in certain circumstances." ${ }^{43}$

In other words, the thirty year limitation period can only be used if the Band can show a reason to postpone the other time periods within the legislation. The key issue for the Court was to determine whether the Crown had post-surrender duties and to locate those duties at specific points in time. It was the specific post-surrender breaches of duty, rather than a continuing breach of duty, which was the key to finding that specific actions of the Crown were not barred by the Limitation Act. The Court said that the proper question was: "having regard to the special relationship between the Crown and the Band, and the conduct of the Crown, when should the Band have been in a position to bring a cause of action?"44

\footnotetext{
4 Semiahmoo, supra note 9 at para. 60.

$42 \quad$ Ibid. at para. 63.

$43 \quad$ Ibid. at para. 55 .

4 Ibid. at para. 72 [emphasis added].
} 
The Court said that the relevant time period for bringing a cause of action for breach of fiduciary duty is six years, pursuant to s. 3(4) of the Limitation Act. This time period will be suspended where there is equitable fraud. With respect to the question of what constitutes "equitable fraud," the Court referred with approval to this often-cited passage in Kitchen v. Royal Air Force Association:" "Conduct, which, having regard to some special relationship between the two parties concerned, is an unconscionable thing for one to do to the other." 46

The Court held that there was equitable fraud, given the relationship between the Crown and the Band. It was held that the Band relied on the Crown for information post-surrender as to the Crown's current and intended uses for the surrendered land. Even though there was no evidence to show that the Crown's overriding intention was to mislead the Band, nonetheless, equitable fraud does not require dishonesty or an improper motive. It requires only that the respondent acted unconscionably with regard to its relationship with the Band.

The Court also said that, in assessing whether to bring a claim under s. 3(4) of the Limitation Act, two conditions must be met: the plaintiff must have sufficient facts on which to bring an action and the plaintiff must have a reasonable prospect of success. This is an objective test. Where facts are concealed, time does not begin to run until the facts are known to the plaintiff, although the time will not run past the thirty year ultimate limitation period.

It was held that the six year limitation period should have started to run on or about 23 May 1989, the date on which DIAND sent a letter to the Band enclosing a consultant's report on the intended use of the surrendered lands. It was at this time that it was clearly indicated that the Crown had no intention of constructing an expanded customs facility on the unused portions of the surrendered land.

It was noted that the Band did not seek legal advice until 1987, and it was not until 1989 that the Band's suspicion that the Crown did not have a foreseeable use for the land was confirmed. The Court asserted:

The Band relied upon the respondent for all of their information post-surrender as to the respondent's current and intended uses for the Surrendered Land. But, whenever the Band sought information from the Crown officials, the latter neglected to provide frank disclosure about their lack of plans for the Surrendered Lands. Instead, they led the Band to believe, each time, that they had definite plans for use of the Surrendered Land or that a study was being conducted to that end. There is no specific evidence to suggest that the respondent's overriding intention was to mislead the Band. However, equitable fraud does not require dishonesty or an improper motive; it requires only that the respondent acted unconscionably having regard to its relationship with the Band. ${ }^{47}$ 
The Court asserted that in determining when a "reasonable person" would seek legal advice, the Band's dependence on the Crown must be taken into account, and the relationship of the parties is also relevant, particularly when there is a fiduciary relationship.

In Apsassin and in Semiahmoo, the courts did not deal with constitutional arguments concerning the application of limitation periods to First Nations. In particular, the courts did not deal with the arguments before them concerning the application of $s .15$ of the Charter in relation to limitations and their effect on First Nations, nor did the courts address the question of whether s. 39 of the Federal Court Act, ${ }^{48}$ by incorporating by reference provincial limitations legislation as federal law, operates to extinguish aboriginal claims absent a clear and plain intention of Parliament to do so.

The Court held that the trial judge erred by focusing on the issue of continuing breach of duty rather than on the fact that the Crown, post-surrender, had a duty to safeguard the interests of the Band as much as possible so long as it retained ownership and control over the surrendered land. Again, the Court said that the proper question is to determine whether this continuing post-surrender duty was breached at any point in time, and not to look for a so-called "continuing breach." This will be of great significance to First Nations. The focus of litigation has often been on the question of whether the Crown breached its duty in obtaining a surrender. The Semiahmoo decision can be used to argue that, even if a surrender has been obtained, one cannot simply say that the Crown is then free to do as it pleases. Once there is a surrender, the Crown continues to be under a duty to protect the interests of First Nations so long as it retains ownership and control over the surrendered land. This means that the Crown's actions must be scrutinized to ensure that it provides full information to First Nations, including various options, such as to sell, lease, or do nothing with their lands. The notion of "minimal impairment of rights" is paramount.

It was found that the 1951 breach was not actionable because of the ultimate thirty year limitation period in the Limitation Act, since the action was not started until 1991. However, it was found that there was a second breach in 1969, when the Crown failed to reconvey the surrendered land to the Band, despite the Band's BCR seeking its return. Between 1951 and 1969, no development had taken place on the land and there were no plans for future development. By 1969, DIAND was, or should have been, aware that the Band wanted the land back. Again, the question should be raised about what would have happened had the land been developed between 1951 and 1969.

This also raises the question of what must be established for a post-surrender breach of duty. Must a First Nation show that it has continuously requested the return of land? Must it show something less, such as that the Crown has acted in a way which is not a minimal impairment of its rights? Must it show some sort of error of the type found limitation of actions in force in any province between subject and subject apply to any proceedings in the Court in respect of any cause of action arising in that province. 
in Apsassin? Is the situation different if it is the Crown, rather than a third party, which holds surrendered land?

Part of the answer lies in the Federal Court of Appeal's comment that the Crown's duty cannot simply be to correct a breach of duty related to the original surrender if such a breach is detected. The Crown has a post-surrender duty to act in the best interests of the Band in relation to all transactions, including the duty to return land if it is not being used for the purpose stated. In other words, the question is not simply whether or not a surrender was properly obtained. Even once there is a surrender, the Crown must continue to act in the best interests of a Band and impair the Band's rights as minimally as possible.

What the Semiahmoo decision does not indicate is whether, had the original surrender been obtained properly and had the Band been fully informed, there could have been a post-surrender breach of duty. It seems unlikely that the Crown would have been relieved of its fiduciary duties, as it could still breach its duties post-surrender by, for example, failing to provide full information to a Band. Since most surrenders are "for lease or sale," the Crown is under a post-surrender duty to act in a way which least impairs a Band's rights. If the Crown does not present options to a Band, such as to lease, rather than sell, in a certain instance, there may be a post-surrender breach of duty. The facts of the Semiahmoo decision are such that it was the improper course of conduct by the Crown from 1951 to the present which formed the basis of the breach of duty.

The Court also noted that it is really only since Guerin that Indian Bands have been able to exercise the same degree of diligence with respect to their legal rights as might be expected of an ordinary member of society. Until then, it could not be said that a reasonable plaintiff would view the Band's cause of action as having a "reasonable prospect of success." 49 This is an interesting point. If it was not until 1984 that a claim could have been launched with any reasonable prospect of success, when the Supreme Court of Canada held in Guerin that the Crown's duties to First Nations were legal, and not simply political, then how could limitations legislation bar claims for return of land, or for damages in lieu thereof, or a combination of both, prior to 1984 ?

\section{REMEDY}

While the aspect of the Court's decision concerning remedies will not be explored at any length, it is worth noting the following findings of the Court with respect to this topic:

1. The Court said that three remedies are available for breach of fiduciary duty: (1) implementation of constructive trust; (2) award of equitable damages; or (3) an accounting for profits. ${ }^{50}$ 
2. The Court noted that it was not clear whether a Band would have to show that the Crown was unjustly enriched if there was a breach of fiduciary duty. In any event, it was held that the fact that the Crown still held that land was sufficient to show unjust enrichment. ${ }^{51}$ The Crown held the land despite knowing that it would not be used for a customs facility. This prevented the Band from using the land as it wished, (i.e. to develop the land and build houses). The Court also pointed out that the land has a unique value to the Band. That the Band obtained market value for the land in 1951 does not detract from the fact that they suffered a deprivation. It was emphasized that the Band would not have surrendered the land in the normal course of events. The Crown's duty did not end "when the Band signed on the dotted line."

3. The remedy of constructive trust is normally used if there is reason to grant the plaintiff the additional rights that flow from recognition of a right of property. The Court asserted that the Crown holds the property for the Band. ${ }^{52}$ It was held that this is an appropriate remedy since the land was unique to the Band, and the Crown had frustrated the Band's attempts to reobtain the property. The Court concluded that as a result of the unique value placed on the land by the Band, an award of monetary damages alone would be insufficient. A constructive trust was placed on all of the land unused for the stated public purpose of constructing a customs facility. The goal was to place the Band in the position it would have been in prior to the 1951 surrender.

4. The Court dealt with the topic of equitable damages, and their availability over and above a constructive trust. This matter was referred to the trial division. There, it would have to be determined whether there were additional amounts required to put the Band in the position it would have been in but for the surrender. ${ }^{53}$ This would have to be offset against the amounts obtained by the Band in relation to the 1951 surrender. The amount obtained by the Band since 1951 was to be calculated on the basis of compound interest. This is interesting, as one would presume that any loss to the Band should be calculated on the same basis. The measure of damages is the actual loss to the Band, based on the presumption that the Band would have used the land in the most advantageous way during the period that it was improperly held by the Crown. The breach in issue is the 1969 breach of duty, since the 1951 breach was barred by the limitations legislation.

5. The Court went even further and remarked that, in calculating damages, it would have to be determined whether the loss of the surrendered land impeded development of the remainder of the reserve. ${ }^{54}$ In particular, the Court said:

Jbid. at para. 91.

lbid. at para. 99.

Ibid. at para. 110.

Ibid. at para. 114. 
In expropriation law, damage to the value of the remainder of a property as a result of a partial taking may be compensable under the principle of injurious affection. Damage by injurious affection, also known as "consequential damage", recognizes inter alia that, "[w]here part of an owner's land is expropriated, the piece or pieces of land remaining may be rendered less valuable as a result of their severance from the expropriated portion. Here a claim may be made for 'injurious affection by severance."'rss

6. Finally, it was held that an accounting for profits was not appropriate. ${ }^{56}$ The disgorgement of profits would in effect punish the Band because the Crown did nothing with the land. Although the Crown did not unfairly obtain profits, the Band did not have use of its lands and therefore was unable to benefit from them.

\section{Conclusion: Significance of the Case}

The Federal Court of Appeal's decision in Semiahmoo is rather startling, for it is one of the few decisions in which a Court has attempted to apply the law of fiduciary duty to the Crown in a principled fashion. While the Federal Court of Appeal recognized that the Crown is unique, it still found that the Crown's behaviour did not meet the requisite standard of care. The Court concluded that the Crown's duty was to prevent exploitative bargains and to impair the Band's rights to the least possible extent. This behaviour will be scrutinized in terms of the way in which a surrender is obtained, as well as the way in which the Crown deals with a First Nation's property after surrender. The Court required that there be disclosure at the level of informed consent. The Crown is required to provide information sufficient to enable a First Nation to decide whether, in a particular instance, it wishes to sell lend, lease land, or do nothing.

Furthermore, the Court also recognized that, while the Crown is made up of many actors in many different departments, it cannot divest itself of a fiduciary duty simply by arguing that there was some sort of internal transfer of land "at arm's length." From a First Nation's point of view, it is "the Crown" with whom it deals. There cannot be a duty on a First Nation to trace property from one Crown department to another in order to determine where a fiduciary duty lies at any given time.

Finally, with respect to limitations legislation, the Court's focus on post-surrender duties provides some hope that many claims of First Nations will not be time-barred. If the focus is not simply on the date of surrender, but on the Crown's actions after surrender, then a provision such as a thirty year ultimate limitation period may not automatically extinguish a claim. By citing the Guerin decision with respect to limitations legislation, the Court recognized that it was really only in 1984, when the Supreme Court of Canada held that the claims of First Nations had legal force and were 
not merely political, that there would be anything approaching a reasonable prospect of success in bringing such claims. "Reasonable prospect of success" is, of course, one of the key tests in determining when a claim must be advanced.

While the Semiahmoo decision is certainly an advance in terms of the way in which the law of fiduciary duty is applied to the Crown-First Nation relationship, it leaves many questions unanswered. In particular, what will constitute an "exploitative bargain" sufficient for the Crown to have breached its duty is not clear, nor is it apparent what sort of disclosure by the Crown will be sufficient to have discharged its fiduciary duty.

In the final analysis, what is missing from the cases conceming the fiduciary duty owed by the Crown to First Nations is a set of clear rules which could be applied with some certainty from one case to another. While the law of fiduciary obligations has developed into a fairly comprehensive code of behaviour within the commercial context, there is still far too much room for judges to pick and choose from the various principles of fiduciary duty and defences open to such claims within the context of the Crown-First Nation relationship. The problem does not result from a lack of coherent legal principles. Instead, the difficulty is in the application of core principles of fiduciary duty to the Crown-First Nation relationship. The Semiahmoo decision could be the starting point in developing a comprehensive code of behaviour which recognizes that the Crown, as fiduciary, must act in a way which protects aboriginal rights. 